\title{
GENETIC DIVERSITY IN EGYPTIAN BUFFALOES (Bubalus bubalis) USING MICROSATELLITE MARKERS \\ Farrag, F.H. ${ }^{1}$; M.S. Hassanane ${ }^{2}$; F.E. El-Keraby ${ }^{3}$ and A.H. Ammar ${ }^{3}$ \\ 1- Anim. Prod. Dept., Fac. Agric., Mansoura University. \\ 2- Anim. Prod. Res. Inst., Agric. Res. Center, Egypt. \\ 3- Department of Cell biology, National Research Center, Egypt.
}

\begin{abstract}
Sixty four blood samples were collected from unrelated buffaloes from different populations representing three suspected breeds (Menofi, Beheri and Saidi). The first population was the middle Delta region included: Kafr El-Sheikh and Menoufia; the second was Alexandria population included Alexandria only, while the third population was Upper Egypt (from Assuite up to Sohaj). Five bovine microsatellites (HEL013; CSSM066; ILSTS005; INRA035 and HEL001) were analyzed in the three different populations of Egyptian buffalo in order to determine the genetic diversity between and within populations as well as assess the purity or the heterogenecity of each population. The tested microsatellites showed polymorphism in all populations meaning that they could be used further in parentage testing as well as mapping of quantitative trait loci (QTLs) in buffalo. Contrarily, the microsatellite HEL001 was monomorphic in the studied populations. A total of 29 alleles were detected across the microsatellite loci when they were screened in all populations. The mean number of alleles per locus was 7.25 alleles. However, the observed number of polymorphic alleles ranged from five (ILSTS005) to ten (HEL013). Heterozygosity and Wright's F-statistics (FIS, FST, and FIT) were calculated to determine the genetic variation in these populations. High values of observed heterozygosities were noticed in all populations, the lowest heterozygosity value was 0.333 which observed in Upper Egypt for ILSTS005. In contrast, a complete heterozygosity value (1.00) was observed in many populations, since it observed in Upper Egypt for HEL013 and INRA035; in Alexandria for HEL013; CSSM066; INRA035 and also was observed in Delta for CSSM066 and HEL013. All FIS values were below the zero, meaning the absence of inbreeding within each population. High averages of gene diversity were noticed for all markers and all populations, ranging from 0.665 to 0.753 with an overall mean of 0.709 . Values of gene flow or migration between populations were high meaning that migration and admixture could have taken place between these populations. Depending on the genetic distances, a dendrogram showing the genetic relationship among the different populations.
\end{abstract}

Keywords: Egyptian buffaloes, microsatellite, gene diversity, genetic distances.

\section{INTRODUCTION}

More than 3,920,000 buffalo animals are raised in Egypt provide $2,300,000$ tons of milk and 270,000 tons of meat (FAO, 2005). Buffaloes were unknown in Egypt during the time of the Pharaohs. Movement of buffaloes to Egypt took place when Arabs took these animals from India after the first invasion in the ninth century. Now the largest buffalo population in the Near East and Europe is centered in Egypt (Bhat, 1992). It is believed that the Egyptian buffalo are of one breed with two vaguely differentiated local types, the Beheri of the Delta and the Saidi of Upper Egypt. They vary in color, size 
and production in accordance with differences in management and environment (El-Itriby, 1974). Several animal breeders reporting that the Delta buffalo is classified into some breeds like Beheri, Menoufi, Baladi

De Hondt and Ghanam (1970), described the karyotype of the Egyptian buffalo, that was later confirmed and fully described by Hassanane (1986), who found that it is consists of 5 meta and submetacentric chromosomes. According to the standard karyotype of buffalo (lannuzzi, 1994), the biarmed chromosomes correspond to the fused $1 / 25 ; 2 / 23 ; 8 / 19$; $5 / 28$ and 16/29 chromosomes of cattle. The remaining 20 pairs are acrocentric and include the sex chromosomes. Syntenic conservation between cattle and river buffalo has been reported by Othman and El Nahas (1998). O'Brien (1991) classified molecular genetic markers into two types, the first are the markers associated with a gene of known function while the second are the markers associated with anonymous gene segments of one sort or another.

In the past, all the studies of population genetic structure used allele frequency data at protein coding (mainly allozyme) to study the genetic diversity (Ward et al., 1992). The recent revolution of molecular biology and the discovering of polymerase chain reaction (PCR), provided new methodologies and new markers for the study of genetic variations at the DNA sequence level (Avise, 1994). Among these markers, simple sequence repeats (microsatellite) loci which have to be common in all eukaryotic genomes. Microsatellite DNA markers are simple sequence repeats (SSR) (Schlotterer et al., 1998 and Karp, 1999) or short tandem repeats (Fong et al,. 2002 and Smithson and Macnair,. 2004) consists of tandemly arranged reiterated units of noncoding DNA sequence, typically ranging between 2-5 base pairs (bp) in length (Bradley and Magee, 2006)

In Egyptian buffalo two studies only dealt with the typing of some bovine microsatellites, the first study to identify the possibility of bovine microsatellites to work with the buffalo genome and polymorphism (Hassanane et al., 2000) and the second to identify the genetic diversity between the Egyptian, Greek and Italian buffalo (Moioli et al., 2001).

The aim of the present study is to use some bovine microsatellite genetic markers to study the genetic diversity between and within buffalo populations kept at different regions of Egypt to answer the question: Is the Egyptian buffaloes belong to one or different breeds?

\section{MATERIALS AND METHODS}

\section{Blood sampling:}

Sixty four blood samples were collected from unrelated buffaloes raised in different regions representing three suspected breeds (Menoufi, Beheri and Saidi). The first region was the middle Delta region included: Kafr El-Sheikh and Menoufia, while Alexandria region included Alexandria only, in contrast Upper Egypt region started from Assuite and ended at Sohaj. The details of the taken samples are shown in Table (1): 
Table (1): Number of samples collected from several regions.

\begin{tabular}{|c|c|c|}
\hline Region & Suspected breed & Number of samples \\
\hline Middle Delta & Menoufi & 32 \\
\hline Alexandria & Beheri & 16 \\
\hline Upper Egypt & Saidi & 16 \\
\hline
\end{tabular}

About $10 \mathrm{ml}$ peripheral blood was collected from the jugular vein of each animal into a tube containing $0.5 \mathrm{ml}$ EDTA $(0.5 \mathrm{M})$ as an anticoagulant. The samples were transferred at $4^{\circ} \mathrm{C}$ and processed for DNA extraction in a period not exceeds 3 days from its arrival to the laboratory.

Isolation and purification of DNA:

DNA was isolated and purified using standard salting out method described by Miller et al. (1988). The stock DNA was kept frozen and its concentration was adjusted to $50 \mathrm{ng} / \mu \mathrm{l}$ before performing the polymerase chain reaction (PCR).

Microsatellites used information:

The microsatellites markers which used in this study were chosen according to a joint meeting recommendation, between the International Society of Animal Genetics (ISAG) and FAO (1998), for genetic diversity studies. Details of these markers are shown in Table (2):

Table (2): Details of the microsatellite markers.

\begin{tabular}{|c|c|c|c|}
\hline Marker & $\begin{array}{c}\text { Chromosome } \\
\text { location }\end{array}$ & Primer sequence & Reference \\
\hline HEL001 & D15S10 & $\begin{array}{l}\text { CAACAGCTATTTAACAAGGA } \\
\text { AGGCTACAGTCCATGGGATT }\end{array}$ & \multirow{2}{*}{$\begin{array}{c}\text { Kaukinen \& } \\
\text { Varvio } \\
\text { (1993) }\end{array}$} \\
\hline HEL013 & D11S15 & $\begin{array}{l}\text { TAAGGACTTGAGATAAGGAG } \\
\text { CCATCTACCTCCATCTTAAC }\end{array}$ & \\
\hline ILSTS005 & D10S25 & $\begin{array}{l}\text { GGAAGCAATGAAATCTATAGCC } \\
\text { TGTTCTGTGAGTTTGTAAGC }\end{array}$ & $\begin{array}{l}\text { Brezinsky et } \\
\text { al. (1993) }\end{array}$ \\
\hline CSSM066 & D14S31 & $\begin{array}{l}\text { ACACAAATCCTTTCTGCCAGCTGA } \\
\text { AATTTAATGCACTGAGGAGCTTGG }\end{array}$ & $\begin{array}{l}\text { Barendse et } \\
\text { al. (1994) }\end{array}$ \\
\hline INRA035 & D16S11 & $\begin{array}{l}\text { ATCCTTTGCAGCCTCCACATTG } \\
\text { TTGTGCTTATGACACTATCCG }\end{array}$ & $\begin{array}{l}\text { Vaiman et al. } \\
\quad(1994)\end{array}$ \\
\hline
\end{tabular}

The standard PCR run cycle was usually as: Primary denaturation : $95{ }^{\circ} \mathrm{C}$ for $3 \mathrm{~min}$. then 35 cycles as : $95^{\circ} \mathrm{C}$ for $15 \mathrm{sec} ; 55-60{ }^{\circ} \mathrm{C}$ for $30-60$ sec; $72{ }^{\circ} \mathrm{C}$ for $30 \mathrm{sec}$. Then, final extension as $72{ }^{\circ} \mathrm{C}$ for $5 \mathrm{~min}$, then $15^{\circ} \mathrm{C}$ forever. For optimization the PCR, both the temperature and time of the annealing temperature were changed.

\section{PCR conditions:}

The PCR reaction volume was $20 \mu \mathrm{l}$ for each sample. The PCR master mix formula contained $50 \mathrm{ng} / \mu$ from the DNA template, $10 \times$ PCR buffer that included $1.5 \mathrm{mM} \mathrm{MgCl} 2$ and $10 \mathrm{pmol}$ from each forward and reverse primers and $200 \mu \mathrm{M}$ final concentration from each dNTP.

The initial PCR cycle was at $95^{\circ} \mathrm{C}$ for $3 \mathrm{~min}, 35$ cycles at $95^{\circ} \mathrm{C}$ for $15 \mathrm{sec}, 55-60{ }^{\circ} \mathrm{C}$ for $30-60 \mathrm{sec}, 72^{\circ} \mathrm{C}$ for $30 \mathrm{sec}$, then final extension at $72{ }^{\circ} \mathrm{C}$ for $5 \mathrm{~min}$ and storage at $15^{\circ} \mathrm{C}$. 
The PCR products were tested for success on $2 \%$ agarose in TAE buffer in a horizontal electrophoresis chamber and stained with ethidium bromide. The successful runs were subjected to the vertical electrophoresis run on $12 \%$ polyacrylamide. The polyacrylamide gels were stained with ethidium bromide and the images were captured using gel documentation system. Allelic sizes were determined using free software namely Lab. Image V2.7 (Proland Co,Germany).

http://www.labimaging.com/servlet/engine/ home/ start.html).

Preparations and staining of the polyacrylamide gels were done using the protocol described by Sambrook et al. (1989).

\section{Statistical analysis:}

Allele frequency was estimated using POPGENE Version 1.31 (Yeh et al., 1999), while the observed and expected number of alleles or heterozygosity, average gene diversity, genetic identity and genetic distance was estimated according to Nei's (1978). The genotype deviation from HardyWeinberg was determined by using chi square test, while phylogenic analysis, average gene diversity was calculated according to Nei's (1987) for each breed and for all breeds together. Polymorphism Information Content (PIC) value for each locus was calculated according to Botstein et al. (1980). F-statistics, FIS, FIT and FST were calculated using updated version from FSTAT software, version 2.9.3.2 (Goudet, 1995). The Tree View 32 software (Page, 1996) was employed to draw the dendrogram showing the genetic distances and relationships between breeds under study. The Dendrogram is based on Nei's (1972) using Genetic distance: Method = UPGMA (computer software), modified from NEIGHBOR procedure of PHYLIP Version 3.5.

\section{RESULTS AND DISCUSSION}

\section{Microsatellite polymorphism:}

Data in Table (3) show that the tested microsatellites showed polymorphism in all populations studied, except the microsatellite HEL001 which was monomorphic. Such trend means that they could be used further in parentage testing as well as mapping of quantitative trait loci (QTLs) in buffalo. A total of 29 alleles were detected across the microsatellite loci when they were screened in all populations. The mean number of alleles per locus (MNA) was 7.25 alleles. However, the observed number of polymorphic alleles ranged from 5 (ILSTS005) to 10 (HEL013).

Table (3): Number and size (bp) of alleles detected in buffalo populations.

\begin{tabular}{|c|c|c|c|c|c|c|c|c|c|c|c|}
\hline Micro- & \multicolumn{1}{|c|}{$\mathbf{N}$} & \multicolumn{1}{|c|}{ Alle size (bp) } \\
satellite & $\mathbf{N}$ & $\mathbf{1}$ & $\mathbf{2}$ & $\mathbf{3}$ & $\mathbf{4}$ & $\mathbf{5}$ & $\mathbf{6}$ & $\mathbf{7}$ & $\mathbf{8}$ & $\mathbf{9}$ & $\mathbf{1 0}$ \\
\hline ILSTS005 & 5 & 173 & 175 & 177 & 179 & 183 & & & & & \\
\hline CSSM066 & 6 & 168 & 172 & 176 & 180 & 186 & 200 & & & & \\
\hline INRA035 & 8 & 100 & 102 & 108 & 110 & 114 & 118 & 120 & 122 & & \\
\hline HEL013 & 10 & 165 & 168 & 171 & 174 & 177 & 180 & 183 & 186 & 189 & 191 \\
\hline
\end{tabular}

$\mathrm{N}$ : Number of alleles 
Soysal et al. (2005) reported that the ILSTS005 microsatellite loci were found to be polymorphic in both Turkish Tarai and Anatolian water buffalo (Bubalus bubalis) populations. This contrasted the present study, wheras the lowest polymorphic microsatellite was with ILSTS005 (5 alleles). However in similar trend with the present results, a lower polymorphism for this microsatellite was observed in Turkish buffalo (Soysal et al., 2005), being only 3 alleles in Anatolian water buffalo populations. Also, Moioli et al. (2001) found that the number of alleles per locus for ILSTS005 was only two alleles for Greek, Italian and Egyptian buffalo populations using 13 polymorphic microsatellite loci. In Southwestern European Bovine breeds, Beja-Pereira et al. (2003) noticed that mean number of alleles per locus was 6.5 for ILSTS005.

It is of interest to note that the microsatellite alleles were found to vary in their numbers and sizes among populations. Some alleles were common in all populations while others were not. Details of the microsatellite alleles for the different microsatellites in different populations are shown in Table (4).

Table (4): Number of alleles for each microsatellite in different buffalo populations and mean number of alleles in each population for all microsatelites.

\begin{tabular}{|c|c|c|c|c|c|c|}
\hline \multirow{2}{*}{ Population } & \multicolumn{4}{|c|}{ Microsatellite } & \multirow{2}{*}{$\mathbf{N}$} & \multirow{2}{*}{$\begin{array}{l}\text { Mean No./ } \\
\text { population }\end{array}$} \\
\hline & CSSM066 & HEL013 & \begin{tabular}{|l|} 
INRA035 \\
\end{tabular} & ILSTS005 & & \\
\hline Upper Egypt & 3 & 4 & 5 & 3 & 15 & 3.75 \\
\hline Alexandria & 6 & 4 & 4 & 4 & 18 & 4.5 \\
\hline Delta & 2 & 7 & 6 & 4 & 19 & 4.75 \\
\hline
\end{tabular}

$\mathrm{N}$ : Total no. of alleles

Generally, the overall mean number of alleles for all microsatellites for all populations was 4.33 (Table 4). In this respect, Barker et al. (1997) found that the mean number of alleles for all river buffalo populations was 3.8 while it was 4.8 for all Swamp buffalo populations. This number is nearly similar to that obtained in our populations (4.33). On the other hand, Moioli et al. (2001) found the higher overall mean number of alleles for all the microsatellites, being (6) for Egyptian buffalo and 5.7 for all Italian, Greek and Egyptian buffalo populations. The obtained lower mean number of alleles in this study (4.33) may be due to the great number of microsatellite (13 microsalelites) and/or the higher number of animals studied by authors. In addition, Van Hooft et al. (2000) recorded high mean number of alleles (7.1) for all wild African buffalo (Syncerus caffer) populations, which means more genetic diversity in these populations. The complete absence of selection could be the main factor affects the allele numbers (Boa, 1993). In contrast Grobler et al., (1996) found that the mean number in another area for African buffalo (Syncerus caffer) populations was (9.1). This variation may be related to the number of animals and microsatellite used. The reported higher mean number of alleles than that obtained in our study may be due to the absence of selection in wild animals. 


\section{Size and frequency of alleles for different microsatalites: Microsatellite ILSTSO05:}

The present results showed that number of alleles of ILSTS005 was 5 , ranging in size from 173 to $183 \mathrm{bp}$. The same results were obtained by Navani et al. (2002). Also, Ritz et al. (2000) found that ILSTS005 gave 5 alleles ranged in sizes from 173 to $186 \mathrm{bp}$ in buffaloes (Bubalus bubalis). However, Moioli et al. (2001) found in both Italian and Greek buffalo that the number of the detected alleles for ILSTS005 was two alleles. Also, Arora et al. (2004) found that this microsatellite gave two alleles in Bhadwary buffalo and three alleles in Tarai buffalo with allele size ranging from 177 to $183 \mathrm{bp}$ in both populations. However, the microsatellite ILSTS005 was polymorphic in both Anatolian and Tarai Turkish buffalo giving 3 alleles (Soysal et al., 2005).

On the other hand, Van Hooft et al. (1999) found that ILSTS005 was polymorphic and gave 7 alleles in African buffalo (Syncerus caffer) with size ranging between 173 and $195 \mathrm{bp}$.

The present results in Table (5) revealed that $A_{4}(179 \mathrm{bp})$ was the most frequent (0.75) in Upper Egypt. In contrast, $A_{5}$ (183 bp) showed the least frequency $(0.10)$ in Delta. However, alleles $A_{3}$ and $A_{4}$ were prevailing alleles, since they found in all populations. However, $A_{5}$ was found only in Delta.

Table (5): Size (bp) and frequency of alleles for microsatellite ILSTS005

\begin{tabular}{|c|c|c|c|c|c|}
\hline Allele & Allele & \multicolumn{5}{|c|}{ Allele frequency } \\
\cline { 3 - 6 } number & Size (bp) & Upper Egypt & Alexandria & Delta & All populations \\
\hline $1\left(A_{1}\right)$ & 173 & 0 & 0.333 & 0.100 & 0.147 \\
\hline $2\left(A_{2}\right)$ & 175 & 0.083 & 0.083 & 0 & 0.059 \\
\hline $3\left(A_{3}\right)$ & 177 & 0.167 & 0.333 & 0.300 & 0.265 \\
\hline $4\left(A_{4}\right)$ & 179 & 0.750 & 0.250 & 0.500 & 0.500 \\
\hline $5\left(A_{5}\right)$ & 183 & 0 & 0 & 0.100 & 0.029 \\
\hline
\end{tabular}

In accordance with the present results, Soysal et al. (2005) found that ILSTS005 was polymorphic in both Turkish Tarai and Anatolian water buffalo (Bubalus bubalis). In comparison with the present results, allelic size ranged from 173 to 183 bp (Navani et al., 2002) in riverine buffalo (Bubalus bubalis), 177 to $183 \mathrm{bp}$ (Arora et al., 2004) in the Northern Indian buffalo (Bubalus bubalis), 173 to 195 bp (Van Hooft et al., 1999) in African buffalo (Syncerus caffer), 182 to198 bp (Mukesh et al., 2004), in Indian zebu cattle and 181 to 193 bp (MacHugh et al., 1997) in Taurine and Zebu cattle. The greater number of alleles may be due to the absence of selection since they are wild animals.

Results in Table (5) show that alleles were distributed at a minimum frequency of 0.083 for $A_{2}$ in Upper Egypt and Alexandria to a maximum frequency of 0.750 for $A_{4}$ in Upper Egypt. In the same time, both of $A_{3}$ and $A_{4}$ (177 and $179 \mathrm{bp}$ ) were found in all, being prevailing alleles, while $A_{4}$ (the most frequent allele) had the highest average frequency all over the alleles (0.5000). However, $A_{5}$ was an exclusive allele because it was found only in Delta. In Upper Egypt, both $A_{1}$ and $A_{5}$ were absent, while $A_{5}$ was absent in both Upper Egypt and Alexandria and was specific exclusive allele in Delta 
population. In the case of $A_{4}$, it was found in all populations, showing the highest frequency in Upper Egypt comparing with other populations.

Upper Egypt population gave 3 alleles upon the recorded 5 alleles, while Delta and Alexandria gave 4 alleles for each. Allele $A_{5}(183 \mathrm{bp}$ ) was found only in Alexandria having frequency of 0.1 . In the same trend, Moioli et al. (2001) found frequency distribution of 34.4 and $38.6 \%$ for the first allele of Italian and Greek, respectively. While the second allele showed 65.6 and $71.4 \%$ for Italian and Greek, respectively.

\section{Microsatellite CSSM066:}

As shown in Table (6) the total number of alleles for CSSM066 was 6 ranged from 168 to $200 \mathrm{bp}$ in size. Soysal et al. (2005) found that CSSM066 was polymorphic in Indigenous Anatolian Water Buffaloes. The observed number of alleles were 8. Also, Armstrong et al., (2006) found that CSSM066 was polymorphic and highly informative in Uruguayan Creole bulls (Bos taurus). Number of alleles for this marker was 7 displaying 180-200 bp in size. Also, Navani et al. (2002) showed that CSSM066 was polymorphic and gave 7 alleles ranged in size from 168 to 202 bp in riverine buffaloes (Bubalus bubalis).

For this microsatelite the allelic size was reported to be 168-202 bp (Navani et al., 2002) in the riverine buffaloes (Bubalus bubalis); 174-186 bp (Arora et al., 2004) in buffaloes of northern India; 168-196 bp (Karthickeyan et al., 2006) for Krishna Valley breed of cattle (Bos indicus); 177-209 bp (Mukesh et al., 2004) in Indian zebu cattle; 180-200 bp (Armstrong et al., 2006) for Uruguayan Creole bulls (Bos taurus), 184-194 bp (Kim et al., 2004) for Korean Goral (Nemorhaedus caudatus).

Table (6): Size (bp) and frequency of alleles for the microsatellite CSSM066.

\begin{tabular}{|c|c|c|c|c|c|}
\hline Allele & Allele & \multicolumn{4}{|c|}{ Allele frequency } \\
\cline { 3 - 6 } number & size & Upper Egypt & Alexandria & Delta & All populations \\
\hline $1\left(A_{1}\right)$ & 168 & 0.417 & 0 & 0.167 & 0.194 \\
\hline $2\left(A_{2}\right)$ & 172 & 0.167 & 0 & 0.083 & 0.083 \\
\hline $3\left(A_{3}\right)$ & 176 & 0 & 0.500 & 0.250 & 0.250 \\
\hline $4\left(A_{4}\right)$ & 180 & 0.417 & 0 & 0.083 & 0.167 \\
\hline $5\left(A_{5}\right)$ & 186 & 0 & 0 & 0.167 & 0.056 \\
\hline $6\left(A_{6}\right)$ & 200 & 0 & 0.500 & 0.250 & 0.250 \\
\hline
\end{tabular}

Results in Table (6) showed that alleles distributed in Upper Egypt population at a minimum frequency of 0.167 for $A_{2}$, while it distributed at a maximum frequency of 0.417 for both $\mathrm{A} 1$ and $\mathrm{A} 4$. On the other hand, A3, A5 and $A 6$ were absent. Whereas, in Alexandria population, the maximum frequency was $(0.50)$ for both $A 3$ and $A 6$, while the others were absent. However, in Delta population, the maximum frequency was $(0.250)$ for both A3 and A6 while the minimum was $(0.083)$ for both A2 and A4. Its worthy noting that the observed 6 alleles were found in Delta population. Further more, A5 was exclusively found in Delta population. Noticeably, the most frequent alleles in all populations were $\mathrm{A} 3$ and $\mathrm{A} 6$. 


\section{Microsatellite INRA035:}

The total number of alleles for microsatellite INRA035 was 8 in all populations. Allele size ranged from 100 to 122 bp (Table 7). For microsatellite INRA035, Navani et al. (2002) found that it was monomorphic with allele size of $135 \mathrm{bp}$ in riverine buffalo (Bubalus bubalis). In nearly similarity, Mukesh et al. (2004) found that the allelic size ranged from 102 to $114 \mathrm{bp}$ in Indian zebu cattle.

Results in Table (7) showed that the most frequent allele in all populations was $A 1$ (0.367) while the least frequent alleles were A3, A4, A5 and A7. However, $A 1$ and $A 2$ undergoing the same trend through the studied populations. Additionally, A3, A4 and A5 were exclusive alleles in Alexandria population, where as, A7 was exclusive in Upper Egypt. Its worthy noting that A1 is a prevailing allele since it distributed in all populations with a highest frequency $(0.500)$ particularly in Delta population.

Table (7): Size (bp) and frequency of alleles for microsatellite INRA035.

\begin{tabular}{|c|c|c|c|c|c|}
\hline $\begin{array}{c}\text { Allele } \\
\text { number }\end{array}$ & Allele & \multicolumn{5}{|c|}{ Allele frequency } \\
\cline { 3 - 6 } & Size (bp) & Upper Egypt & Alexandria & Delta & All populations \\
\hline $1\left(A_{1}\right)$ & 100 & 0.375 & 0.200 & 0.500 & 0.367 \\
\hline $2\left(A_{2}\right)$ & 102 & 0.125 & 0.100 & 0.167 & 0.133 \\
\hline $3\left(A_{3}\right)$ & 108 & 0 & 0.100 & 0 & 0.033 \\
\hline $4\left(A_{4}\right)$ & 110 & 0 & 0.100 & 0 & 0.033 \\
\hline $5\left(A_{5}\right)$ & 114 & 0 & 0.100 & 0 & 0.033 \\
\hline $6\left(A_{6}\right)$ & 118 & 0.250 & 0 & 0.083 & 0.100 \\
\hline $7\left(A_{7}\right)$ & 120 & 0.125 & 0 & 0 & 0.033 \\
\hline $8\left(A_{8}\right)$ & 122 & 0.125 & 0.400 & 0.250 & 0.267 \\
\hline
\end{tabular}

For microsatellite INRA035, Mukesh et al. (2004) found that it was informative and polymorphic exhibiting different allele sizes ranged from 102$114 \mathrm{bp}$ in Indian native cattle. The observed number of alleles was 7, 8 and 8 for Sahiwal, Hariana and Deoni cattle breeds, respectively. Also, Pandey et al. (2006) reported that it was polymorphic and gave seven alleles in Kherigarh breed of Indian zebu cattle (Bos indicus). Mean number of alleles per locus was 6.24. Moreover, Karthickeyan et al. (2006) found that it was polymorphic and highly informative, giving 7 alleles with high PIC (0.798) in Krishna Valley breed of cattle (Bos indicus) in South India.

\section{Microsatellite HEL013:}

The total number of alleles which observed for microsatellite HEL013 was 10 alleles ranging from 165 to $191 \mathrm{bp}$ in zise (Table 8). The same range of size was recorded by Navani et al. (2002) in riverine buffaloes. However, the alleles sizes ranged from 188 to 198 bp for Korean Goral (Nemorhaedus caudatus, Kim et al., 2004) and from 177 to $197 \mathrm{bp}$ in lowland European bison (Bison bonasus bonasus, Gralak et al., 2004).

For all populations, the highest frequency was observed for alleles $A_{2}$ and $A_{9}$ (168 and $189 \mathrm{bp}$ ), being the highest $(0.50)$ in Delta and Upper Egypt. It is of interest to note that alleles $A_{1}, A_{5}, A_{6}$ and $A_{8}$ showed lower frequency for all populations and were found only in Alexandria $\left(A_{1}, A_{5}\right.$ and $\left.A_{6}\right)$ and 
Delta $\left(A_{8}\right)$. However, alleles $A_{3}$ and $A_{9}$ showed the same trend and were found only in Upper Egypt. Finally, $A_{10}$ was absent in Upper Egypt and showed lower frequency (0.083) in Alexandria and Delta (Table 8).

Table (8): Size (bp) and frequency of alleles for microsatellite HEL013

\begin{tabular}{|c|c|c|c|c|c|}
\hline Allele & Allele & \multicolumn{5}{|c|}{ Allele frequency } \\
\cline { 3 - 6 } number & size (bp) & Upper Egypt & Alexandria & Delta & All populations \\
\hline $1\left(A_{1}\right)$ & 165 & 0 & 0.167 & 0 & 0.056 \\
\hline $2\left(A_{2}\right)$ & 168 & 0.333 & 0.083 & 0.500 & 0.306 \\
\hline $3\left(A_{3}\right)$ & 171 & 0.083 & 0 & 0 & 0.028 \\
\hline $4\left(A_{4}\right)$ & 174 & 0.083 & 0.167 & 0 & 0.083 \\
\hline $5\left(A_{5}\right)$ & 177 & 0 & 0.250 & 0 & 0.083 \\
\hline $6\left(A_{6}\right)$ & 180 & 0 & 0.083 & 0 & 0.028 \\
\hline $7\left(A_{7}\right)$ & 183 & 0 & 0.167 & 0.250 & 0.139 \\
\hline $8\left(A_{8}\right)$ & 186 & 0 & 0 & 0.167 & 0.056 \\
\hline $9\left(A_{9}\right)$ & 189 & 0.500 & 0 & 0 & 0.167 \\
\hline $10\left(A_{10}\right)$ & 191 & 0 & 0.083 & 0.083 & 0.056 \\
\hline
\end{tabular}

Based on these results, $A_{2}$ is a prevailing allele which found in all population, while $A_{1}, A_{3}, A_{5}, A_{6}, A_{8}$ and $A_{9}$ were exclusive alleles.

By studying a set of cattle microsatellite DNA markers for genome analysis of riverine buffalo (Bubalus bubalis), Navani et al. (2002) found that microsatellite HEL013 was polymorphic giving 5 alleles ranging in size from 165 to $191 \mathrm{bp}$. Also, Kim et al. (2004) showed that this microsatellite was polymorphic in Korean Goral (Nemorhaedus caudatus) displaying 3 alleles ranging size of 188-189 bp. Armstrong et al. (2006) found in Uruguayan Creole bulls (Bos taurus) that microsatellite HEL013 was polymorphic and number of alleles was 3 displaying sizes from 184 to $192 \mathrm{bp}$.

On the other hand, microsatellite HEL013 was non polymorphic in comparing three breeds of Bovidae family, European bison (Gralak et al, (2004), American bison (Mommens et al., 1998) and three Polish cattle breeds (Lubieniecka et al., 2001).

Prevailing and exclusive alleles:

Prevailing alleles refer to common alleles with the highest frequency among the populations while, exclusive alleles refer to unique alleles or breed specific allele. The exclusive alleles always have extreme value for minimum and maximum frequency values (Arranz et al., 2001).

Results in Table (9) revealed that CSSM066 showed prevailing of $A_{1}$ and $A_{4}$ in Upper Egypt, while $A_{3}$ and $A_{6}$ were prevailing in Delta and Alexandria. In contrast, $A_{5}$ was exclusively specific to the Delta. However, HEL013 exhibited three prevailing alleles, $A_{10}$ in Upper Egypt, $A_{2}$ in Delta and $A_{5}$ in Alexandria, whereas $A_{1}, A_{3}, A_{5}, A_{6}, A_{8}$ and $A_{10}$ were exclusive alleles in their correspondent populations.

Microsatellite INRA035 displayed the prevailing of $A_{1}$ in Upper Egypt and Delta, while $A_{8}$ was prevailing in Alexandria. However, $A_{7}$ was exclusive in Upper Egypt, but $A_{3}, A_{4}$, and $A_{5}$ were exclusive in Alexandria. The microsatellite ILSTS005 showed four prevailing alleles, $A_{4}$ in Upper Egypt and Alexandria, both $A_{1}$ and $A_{3}$ in Delta, whereas $A_{5}$ was exclusively specific in Alexandria (Table 9). 
Farrag, F.H. et al.

Table (9): Prevailing and exclusive allele numbers (preceding the brackets) and their frequency (between brackets) for each microsatelite in different populations.

\begin{tabular}{|c|c|c|c|c|c|c|}
\hline \multirow{2}{*}{ Locus } & \multicolumn{3}{|c|}{ Prevailing alleles } & \multicolumn{3}{c|}{ Exclusive alleles } \\
\cline { 2 - 7 } & $\begin{array}{c}\text { Upper } \\
\text { Egypt }\end{array}$ & Alexandria & Delta & $\begin{array}{c}\text { Upper } \\
\text { Egypt }\end{array}$ & Alexandria & Delta \\
\hline CSSM066 & $1-4(0.417)$ & $3-6(0.50)$ & $3-6(0.250)$ & - & - & $5(0.167)$ \\
\hline \multirow{2}{*}{ HEL013 } & $10(0.5)$ & $5(0.250)$ & $2(0.5)$ & $3(0.083)$ & $1(0.167)$ & $8(0.167)$ \\
& & & & $10(0.5)$ & $\begin{array}{c}5(0.250) \\
6(0.083)\end{array}$ \\
\hline INRA035 & $1(0.375)$ & $8(0.400)$ & $1(0.5)$ & $7(0.125)$ & $3-4-5(0.1)$ & - \\
\hline ILSTS05 & $4(0.750)$ & $4(0.500)$ & $1-3(0.333)$ & - & $5(0.1)$ & - \\
\hline
\end{tabular}

\section{Observed and expected heteroxygosity:}

Average observed heterozygosity for all populations were higher than the expected. This can be considered as an indication of heterozygosity excess in all populations. Excluding the monomorphic microsatellite HEL001, all microsatellites studied were heterozygous polymorphic. No homozygous alleles for any microsatellite were observed in any population.

Results in Table (10) show that HEL013 had polymorphic pattern in all populations. However, the mean number of alleles for HEL013 in all populations was 5, which was higher than 4.5 alleles (Navani et al., 2002) and higher than 2.6 alleles (Kim et al., 2004). Meanwhile, the polymorphism information content (PIC) was 0.64, being higher than 0.27 (Armstrong et al., 2006). However, the present mean heterozygosity typed by HEL013 for all populations was one, being higher than 0.66 (Navani et al., 2002 and Kumar et al., 2003); 0.55 (MacHugh et al., 1997); 0.50 (Kim et al., 2004); 0.33 (Armstrong et al., 2006) and 0.65 (Eveline et al., 2004).

On the other hand, Gralak et al. (2004) reported that HEL013 failed to amplify or produce trace signal when it used with Bison (Bison bonasus bonasus).

Microsatellite ILSTS005 displayed a polymorphic pattern in all populations. Its mean number of alleles in all populations was 3.67 , being higher than 2 (Moioli et al., 2001) and lower than 4.5 (Navani et al., 2002), 4.8 (MacHugh et al., 1997) and 10.16 (Arranz et al., 1996). However, the mean heterozygosity exhibited by ILSTS005 for all populations was 0.60 . The same result was reported by Kantanen et al. (2000). However the present mean heterozygosity was higher than 0.16 (Moioli et al., 2001); 0.56 (Barker et al., 1997); 0.51 (Arrora et al., 2004) and 0.55 (Soysal et al., 2005), while it was lower than 0.62 (Navani et al., 2002), 0.68 (Pandy et al., 2006), 0.74 (Karthickeyan et al.,2006), 0.64 (Mukish et al., 2004), 0.66 (Beja-Perera et al., 2003 and Kumar et al., 2003) and 0.67 (Kim et al., 2004).

Microsatellite ILSTS005 was informative since the mean PIC was 0.53 in all populations, being higher than 0.42 (Soysal et al., 2005), 0.40 (Arora et al., 2004) and lower than 0.67 (Pandy et al., 2006) and 0.70 (Karthickeyan et al., 2006).

Microsatellite CSSM066 showed a polymorphic pattern in all populations. Its mean number of alleles in all populations was 3.67 , being 
lower than 4.5 (Navani et al., 2002), 4.7 (Arora et al., 2004), 5.8 (Mukesh et al., 2004), 6.75 (Soysal et al., 2005), 6.5 (Beja-Perera et al., 2003), 5.45 (Kumar et al., 2003) and 4.72 (Karthickeyan et al., 2006).

The mean heterozygosity displayed by microsatellite CSSM066 for all populations was 0.94, being higher than 0.53 (Moore et at., 1995), 0.69 (Karthickeyan et al., 2006); 0.78 (Soysal et al., 2005), 0.64 (Arora et al., 2004), 0.84 (Navani et al., 2002), 0.65 (Mukesh et al., 2004), 0.60 (Kantanen et al., 2000), 0.66 (Beja-Perera et al., 2003), 0.66 (Kumar et al., 2003) and 0.67 (Kim et al., 2004). While Armstrong et al. (2006) reported higher mean heterozygosity, being one.

Microsatellite CSSM066 was informative since the mean PIC in all populations was 0.58 , being higher than 0.49 (Soysal et al., 2005) and 0.24 (Gralak et al., 2004), nearly similar to 0.56 (Arora et al., 2004) and lower than 0.66 (Karthickeyan et al., 2006) and 0.79 (Armstrong et al., 2006).

Microsatellite INRA035 exhibited a polymorphic pattern in all populations, showing 8 alleles versus 7 alleles (Pandey et al., 2006 and Mukesh et al., 2004) and 4.72 alleles (Karthickeyan et al., 2006). Its mean heterozygosity in all populations was 0.89 versus 0.72 (Pandey et al., 2006); 0.70 (Mukesh et al., 2004); 0.60 (Kantanen et al., 2000); 0.66 (Beja-Perera et al., 2003 and Kumar et al., 2003) and 0.82 (Karthickeyan et al., 2006).

Table (10): Microsatellite alleles (No, observed number of alleles; $\mathrm{Ne}$, effective number of alleles), heterozygosity (Ho, observed; $\mathrm{He}$, expected) and polymorphism information content (PIC) at each locus in the different populations under study.

\begin{tabular}{|c|c|c|c|c|c|c|c|}
\hline \multicolumn{3}{|l|}{ Population } & HEL013 & ILSTS005 & CSSM066 & INRA035 & Mean \\
\hline \multirow{5}{*}{ Upper Egypt } & \multirow{2}{*}{ Alleles } & No & 4 & 3 & 3 & 5 & 3.750 \\
\hline & & $\mathrm{Ne}$ & 2.667 & 1.674 & 2.667 & 4.000 & 2.752 \\
\hline & \multirow{2}{*}{ Het. } & $\mathrm{Ho}$ & 1.000 & 0.333 & 0.833 & 1.000 & 0.792 \\
\hline & & $\mathrm{He}$ & 0.682 & 0.439 & 0.682 & 0.875 & 0.665 \\
\hline & \multicolumn{2}{|c|}{ PIC } & 0.611 & 0.278 & 0.602 & 0.698 & 0.548 \\
\hline \multirow{5}{*}{ Alexandria } & \multirow{2}{*}{ Alleles } & No & 7 & 4 & 2 & 6 & 4.75 \\
\hline & & $\mathrm{Ne}$ & 2.880 & 3.429 & 5.143 & 2.880 & 3.583 \\
\hline & \multirow{2}{*}{ Het. } & $\mathrm{Ho}$ & 1.000 & 0.800 & 1.000 & 1.000 & 0.950 \\
\hline & & $\mathrm{He}$ & 0.909 & 0.711 & 0.546 & 0.844 & 0.753 \\
\hline & \multicolumn{2}{|c|}{ PIC } & 0.571 & 0.693 & 0.691 & 0.571 & 0.632 \\
\hline \multirow{5}{*}{ Delta } & \multirow{2}{*}{ Alleles } & No & 4 & 4 & 6 & 4 & 4.50 \\
\hline & & $\mathrm{Ne}$ & 6.000 & 2.778 & 2.000 & 4.167 & 3.736 \\
\hline & \multirow{2}{*}{ Het. } & $\mathrm{Ho}$ & 1.000 & 0.667 & 1.000 & 0.667 & 0.833 \\
\hline & & $\mathrm{He}$ & 0.712 & 0.773 & 0.879 & 0.712 & 0.769 \\
\hline & \multicolumn{2}{|c|}{$\mathrm{PIC}$} & 0.738 & 0.611 & 0.438 & 0.745 & 0.633 \\
\hline
\end{tabular}

\section{Average gene diversity:}

Average gene diversity for all microsatellites in all populations (Table 11) for all loci was 0.720 , ranging between 0.439 for ILSTS005 in Upper Egypt and 0.910 for HEL013 in Delta. As expected, the microsatellite loci showed high genetic diversity for each microsatellite in all populations ranging from 0.62 for ILSTS005 to 0.800 for INRA035. The lowest gene diversity for ILSTS005 was mainly related to the lower number of alleles, being 5 as compared to 10 alleles for HEL013. Moioli et al. (2001) noticed 
Farrag, F.H. et al.

similar trend during studying the genetic diversity between the Egyptian, Italian and Greek buffalo using microsatellite markers.

Table (11): Average gene diversity for all microsatellites in all populations studied.

\begin{tabular}{|l|c|c|c|c|}
\hline \multirow{2}{*}{ Area } & \multicolumn{4}{|c|}{ Microsatellite marker } \\
\cline { 2 - 5 } & HEL013 & ILSTS005 & CSSM066 & INRA035 \\
\hline Upper Egypt & 0.682 & 0.439 & 0.682 & 0.857 \\
\hline Alexandria & 0.712 & 0.733 & 0.879 & 0.712 \\
\hline Delta & 0.910 & 0.711 & 0.545 & 0.844 \\
\hline Mean & 0.760 & 0.620 & 0.700 & 0.800 \\
\hline
\end{tabular}

The present results are similar to previously reported by Loftus et al. (2002), being 0.78 during their study concerning the identification of zebu alleles in some cattle breeds including Egyptian cattle.

\section{Inbreeding Measures:}

To assess genetic differentiation within each population, Fis is a measure of the within population heterozygote defect (inbreeding). Table (12) shows estimates of within the populations inbreeding (Fixation index statistics, $\mathrm{FIS}=f$ ).

Table (12): Inbreeding or Fixation index (Fis $=f$ ) within population heterozygosity deficit for each of the studied loci in the populations.

\begin{tabular}{|c|c|c|c|}
\hline \multirow{2}{*}{ Locus } & \multicolumn{3}{|c|}{ Population } \\
\cline { 2 - 4 } & Upper Egypt & Alexandria & Delta \\
\hline CSSM66 & -0.333 & -0.241 & -1.000 \\
\hline HEL013 & -0.600 & -0.532 & -0.200 \\
\hline INRA05 & -0.333 & -0.021 & -0.316 \\
\hline ILSTS05 & -0.172 & -0.059 & -0.250 \\
\hline Mean & -0.274 & -0.184 & -.441 \\
\hline
\end{tabular}

It could be noticed that all the observed values were below the zero and they were approximately near to zero which means the complete absence of inbreeding with each population (Table 12). This result is expected since the materials and methods of the present study are following the regulations of FAO for domestic animals diversity (DAD) which advise by taking samples from unrelated animals. Similar results were observed in Egyptian buffalo populations on genetic diversity between and within Egyptian, Italian and Greek buffalo by Moioli et al. (2001).

\section{Gene flow:}

Gene flow was estimated according to Nei's (1987) indicating the ratio of the migrants exchanged from one generation to another. The lowest value of genetic differentiation between populations is supported by high level of gene flow between each two breeds (Table13). The highest value of the gene 
flow was observed between Alexandria and Delta populations which also have the lowest value of $\mathrm{FST}_{\mathrm{ST}}$, as a genetic differentiation. That could be explained by the geographical proximity of the two breeds.

Table (13): Estimated pair-wise $F_{s t}$ as a measure of the between populations differentiation (above diagonal) and gene flow (below diagonal) between pairs of the studied groups.

\begin{tabular}{|l|c|c|c|}
\hline Populations & Upper Egypt & Alexandria. & Delta \\
\hline Upper Egypt & ----- & 0.102 & 0.139 \\
\hline Alexandria. & 2.192 & ----- & 0.069 \\
\hline Delta & 1.547 & 3.399 & ----- \\
\hline \multicolumn{2}{r|r}{ The obtained results are expected as a result of absence of } \\
\cline { 1 - 4 }
\end{tabular}
inbreeding between the different populations. No doubt, this is expected since the regions included in this study are far from each other and the possibility of exchanging animals is relatively low.

\section{Genetic distance and Identity:}

Genetic distance is a measure based on shared alleles between breeds (Table 14). Genetic distance shows compatible result with the genetic differentiation measure Fst. Genetic distance showed low values between all populations which reflect genetic similarity among the studied populations (Table 14).

Table (14): Nei's genetic identity (above diagonal) and genetic distance (below diagonal)

\begin{tabular}{|c|c|c|c|}
\hline Populations & Upper Egypt & Alexandria & Delta \\
\hline Upper Egypt & ------ & 0.579 & 0.423 \\
\hline Alexandria & 0.546 & ----- & 0.667 \\
\hline Delta & 0.856 & 0.405 & ------- \\
\hline
\end{tabular}

The lowest genetic distance was between Alexandria and Delta populations $(0.405)$ agreeing with the highest genetic identity $(0.667)$ and highest gene flow between them (3.399). In contrast, the highest genetic distance was observed between Upper Egypt and Delta (0.856) agreeing with the lowest genetic identity (0.429) and lowest gene flow between them (1.547). Genetic distance shows compatible result with the genetic differentiation measure $F_{S T}$.

\section{Genetic divergence:}

Genetic divergence is another measure of how breeds differ from each other in terms of time. Nei (1978) calculated genetic divergence $\left(D_{s}\right)$ as

$$
D_{s}=2 a t, \quad \text { i.e. } t=D_{s} *(2 \alpha)^{-1}
$$

Where $\alpha$ is microsatellite mutation rate and $t$ is the number of generations. The average mutation rate of human loci $\left(1.2^{*} 10^{-3}\right)$ as reported by Weber and Wong (1993) and a generation interval of 4.35 years were used in the present study to calculate number of years separating any two populations. 
Farrag, F.H. et al.

Genetic divergence analysis shows that the highest divergence time was 1209 years between Upper Egypt and Delta (Table 15), while the lowest was 771 years between Alexandria and Delta.

Table (15): Estimated divergence time of the breeds under study on the basis of the 4 microsatellite loci studied.

\begin{tabular}{|c|c|c|c|c|}
\hline Population & \multirow{2}{*}{ NSGD } & Mutation rate & \multicolumn{2}{|c|}{ Divergence time } \\
\cline { 4 - 5 } & & $(\boldsymbol{\alpha})$ & Generations & Years \\
\hline Upper Egypt \& Alexandria & 0.579 & & 241 & 1048 \\
\hline Upper Egypt \& Delta & 0.667 & \multirow{2}{*}{$1.2 \times 10^{-3}$} & 278 & 1209 \\
\cline { 1 - 2 } & & & 177 & 771 \\
\hline
\end{tabular}

NSGD: Nei's standard genetic distance (Ds)

The results of this table are confirming the phylogeny dendrogram number (1) obtained using UPGMA method.

\section{Relationship dendogram:}

The dendogram (1) illustrated below shows separation between Delta, Alexandria and Upper Egypt. The first two were separated together in one sub cluster while Upper Egypt was located in the other sub cluster. It indicates the expected phylogeny tree for the divergence of the different populations from each other.

The populations of Alexandria and Delta showed the lowest divergence, while the greatest differentiation was detected between Delta and Upper Egypt populations. The dendogram confirms the results obtained in Table (15).

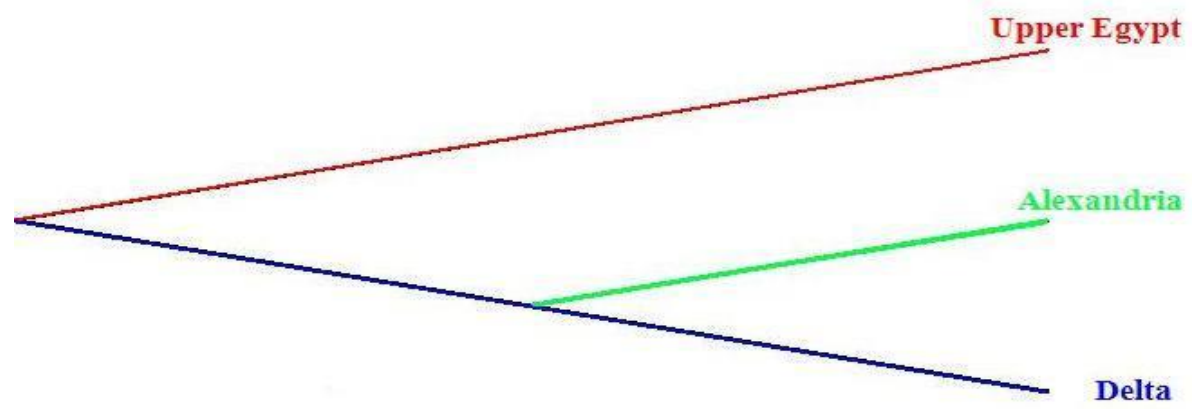

Dendogram (1): Phylogenetic tree representing relationship between the three buffalo populations using genetic distance based on four microsatellite loci.

\section{Conclusion:}

1 - Bovine markers used successfully in buffalo.

2 - Most of the markers displaying polymorphic pattern indicating that all the buffalo populations represented only one breed and the phenotypic differences are due to the environmental factors.

3 - More bovine microsatellites must be used in the coming researches. 


\section{REFERENCES}

Armstrong E., Alicia Postiglioni, Amparo Martinez, Gonzalo Rincón and José Luis Vega-Pla (2006). Microsatellite analysis of a sample of Uruguayan Creole bulls (Bos taurus). Genetics and Molecular Biology, 29, 2, 267272.

Arora, R.; B.D. Lakhchaura; R.B. Prasad, M.S. Tantia and R.K. Vijh (2004). Genetic diversity analysis of two buffalo populations of northern India using microsatellite markers. J. Animal. Breed. Genet. 121(2) , 111118.

Arranz, J.J.; Bayon, Y.; San Primitivo, F. (1996). Comparison of protein markers and microsatellites in differentiation of cattle populations. Animal Genetics. 27(6):415-419

Arranz, J.J.; Bayon, Y. and San primitivo, F. (2001). Differentiation among Spanish sheep breeds using microsatellites. Genet. Sel. Evol., 33(5):529-542.

Avise, J.C. (1994): Molecular Markers, Natural History and Evolution. Chapman and Hall, New York.

Barker, J.S.F.; Tan, S.G.; Selvaraj, O.S. and Mukherjee, T.K. (1997): Genetic variation within and relationships among populations of Asian water buffalo (Bubalus bubalis). Animal Genetics, 28: 1-13.

Beja-Pereira, A.; Alexandrino, P.; Bessa, I.; Carretero, Y.; Dunner, S.; Ferrand . N.; Jordana, J.; Laloe, D.; Moazami-Goudarzi, K.; Sanchez, A. and Canon, J. (2003). Genetic Characterization of Southwestern European Bovine Breeds: A Historical and Biogeographical Reassessment With a Set of 16 Microsatellites. Journal of Heredity, 94(3):243-250.

Bhat, P.N.(1992). Genetic of river buffaloes.In: (eds) Tulooh, M. H. and Holmes, J. H. G. Buffalo production, production-system approach. Elsevier Scientific Publications ,Amsterdam, Netherlands .pp.13-52.

BOA (1993). Board of Agriculture, Managing global genetic resources livestock. Committee on Managing Global Genetic Resources: Agricultural Imperatives, National Research Council. National Academy Press, Washington, D.C., USA, $276 \mathrm{pp}$.

Botstein D., White R. L., Skolnick M. and Davis R. W. (1980). Construction of a genetic linkage map in man using restriction fragment length polymorphisms. Am. J. Hum. Genet. 32, 314-331.

De Hondt, H.A. and Ghanam, S.A. (1971): Cytogenetic studies of the Egyptian water buffalo (Bubalus bubalis). Z. Tierzuchg. Zuchtgsbiol., 88 (1): 64-68.

El-Itriby, A.A. (1974): The buffalo in the Arab Republic of Egypt. In The husbandry and health of the domestic buffalo, W. Ross Cockrill (Editor). Food and Agriculture Organization of the United Nations, Rome, Italy.

Eveline M.; Ibeagha A.; Oliver C. J.; Christina W. and George E. (2004). Genetic diversity, introgression and relationships amongWest/Central African cattle breeds. Genet. Sel. Evol. 36 (2004) 673-690. 
Food and Agriculture Organization of the United Nations FAO (1998), Rome: Secondary Guidelines for Development of National Farm Animal Genetic Resources Management Plans. Measurement of Domestic Animal Diversity (Mo-DAD): Original Working Group Report. http://dad.fao.org/en/refer/library/guidelin/workgrp.pdf

FAO, Food and Agriculture Organization of the United Nations (2005). FAOSTAT online statistical service. FAO. http://www.fao.org

Fong, M.K.;Sekido, Y. and Minna, D. J.(2002).The Molecular basis of lung carcinogenesis in: Coleman, B. W.; and Tsongalis, J. G.(eds).The Molecular Basis of Human Cancer. Humana press, Totowa, USA. Pp 379-406

Goudet, J. (1995). FSTAT version 1.2: a computer program to calculate F statistics. Journal of Heredity, 86 (6): 485-486.

Gralak B., Krasinska M., Niemczewski C., Krasmski Z.A. and Zurkowski M. (2004). Polymorphism of bovine microsatellite DNA sequences in the lowland European bison. Acta theriol., 49, N (4): 449-456.

Grobler, J. P. and VAN DER Bank., F. H. (1996). Genetic Diversity and isolation in African Buffalo (Syncerus caffer). Biochemical Systematics and Ecology, Vol. 24, No. 7/8, pp. 757-761.

Hassanane, M.S. (1986): Cytological studies n Egyptian water buffalo, M.Sc. thesis, Department of Genetics, Faculty of agriculture, Cairo University. June, 1986.

Hassanane, M.S.; Aasland, M.; Klungland, H. and Vage, D.I. (2000). Five bovine microsatellites showing polymorphism in river buffalo (Bubalus bubalis). Egyptian J. Animal Production, 37(2): 77-84.

lannuzzi, L. (1994): Coordinator. Report of the committee for the standardization of banded karyotypes of the river buffalo: Standard karyotype of the river buffalo (Bubalus bubalis L., $2 n=50$ ). Cytogenet Cell Genet. 67: 102-113.

Kantanen, J.; Olsaker, I.; Holm, L.E.; Lien, S.; Vilkki, J.; Brusgaard, K.; Eythorsdottir, E.; Danell, B. and Adalsteinsson, S. (2000). Genetic diversity and population structure of 20 North European cattle breeds. J. Hered. 91: 446-57.

karp, A. (1999). The use of polymorphic microsatellite for assessing genetic diversity in coconut in: (eds) Oropeza, C.; Verdeil, J. L.; Ashburner, G. R.; Cardeña, R. and Santamaría, J. Current Advances in Coconut Biotechnology. Kluwer Academic Publishers (Dordrecht / Boston / London) Pp 121-130.

Karthickeyan, S.M.K.; R. Saravanan and P. Thangaraju (2006). Characterization of Krishna Valley breed of cattle (Bos indicus) in south India using microsatellite markers. Livestock Research for Rural Development 18 (12) :35-40.

Kim, K.S. Min, M.S. AN, J.H. And Lee, H. (2004). Cross-Species Amplification of Bovidae Microsatellites and Low Diversity of the Endangered Korean Goral. Journal of Heredity, 95(6):521-525.

Kumar, P., Freeman, A.R., Loftus, R.T., Gaillard, C., Fuller, D.Q. and Bradley, D.G. (2003). Admixture analysis of South Asian cattle. Heredity. 91 : 43-50. 
Lubieniecka, J.; Grzybowski, G. and Lubieniecki K. (2001). Genetic variation in nine European cattle breeds as determined on the basis of microsatellite markers. I. Within-breed variation. Animal Science Papers and Reports 19 (4): 249-264.

Loftus, R.T.; Ertugrul, O.; Harba, A.H.; El-Barody, M.A.; MacHugh, D.E.; Park, S.D. and Bradley, D.G. (2002): A microsatellite survey of cattle from a centre of origin: the Near East. Mol Ecol. 8(12):2015-2022

MacHugh, D.E.; Shriver, M.D.; Loftus, R.T.; Cunningham, P. and Bradley, D.G. (1997). Microsatellite DNA variation and the evolution, domestication and phylogeography of taurine and zebu cattle (Bos taurus and Bos indicus). Genetics, 146: 1071-1086.

Miller, S.A.; Dykes, D.D. and Polesky, H.F. (1988). A simple salting out procedure for extracting DNA from human nucleated cells. Nucleic Acids Research, 16: 1215.

Moioli, B.; Georgoudis, A.; Napolitano, F.; Catillo, G.; Giubilei, E.; Ligda, Ch. and Hassanane, M. (2001). Genetic diversity between Italian, Greek and Egyptian buffalo populations. Livestock Production Science, 7(3): 203-211.

Mommens G., Van Zeveren A. and Peelman L. J. (1998). Effectiveness of bovine microsatellites in resolving paternity cases in American bison, Bison bison L. Animal Genetics 29: 12-18.

Moore, S.S.; D. Evans, K. Byrne, J.S.F. Barker, S.G. Tan, D. Vankan, D.J.S. Hetzel. (1995). A set of polymorphic DNA microsatellites useful in swamp and river buffalo (Bubalus bubalis). Animal Genetics, , 26, 355359.

Mukesh M.; Sodhi M.; Bhatia1 S. and Mishra B. P. (2004). Genetic diversity of Indian native cattle breeds as analysed with 20 microsatellite loci. J. Anim. Breed. Genet. 121 (2004), 416-424.

Navani, N, P. K. Jain, S. Gupta, B. S. Sisodia and S. Kumar, (2002). A set of cattle microsatellite DNA markers for genome analysis of riverine buffalo (Bubalus bubalis). Animal Genetics,33, 149-154.

Nei, M. (1972): Genetic distance between populations. Am. Nat. 106: 283292.

Nei, M. (1978): Estimation of average heterozygosity and genetic distance from a small number of individuals. Genetics 89, 583-590.

Nei, M. (1987): Molecular Evolutionary Genetics, pp512. Columbia University Press, New York, USA.

Othman, O.E. and El Nahas, S. (1998): Synteny assignment of four genes and two microsatellite markers in river buffalo (Bubalus bubalis L.). J. Anim. Breed. Genet. 116: 161-168.

O'Brien, S.J. (1991): Mammalian genome mapping: lessons and prospects. Curr. Opin. Genet. Dev., 1: 105-111.

Pandey A.K., Rekha Sharma, Yatender Singh, B.B. Prakash and S.P.S. Ahlawat (2006). Genetic diversity studies of Kherigarh cattle based on microsatellite markers. Journal of Genetics, Vol. 85, No. 2

Ritz, L.R., Glowatzki, M.L., MacHugh, D.E. and Gaillard, C. (2000) Phylogenetic analysis of the tribe Bovini using microsatellites. Animal Genetics 31: 178-185.

Sambrook, J.; Fritsch, E. F. and Maniatis, T. (1989): Molecular Cloning - A Laboratory Manual, Cold Spring Harbor Laboratory Press 
Farrag, F.H. et al.

Schlotterer, C. and Pemberton, J. (1998). The use of microsatellite for genetic analysis of nature populations in: deSalle, R. and Schierwater, B. (eds.) Molecular approaches to ecology and evolution. Birkhäuser Verlag AG, Basel, Switzerland. pp. 71-86.

Smithson, A. and Macnair, M.R. (2004). Have recent developments in molecular techniques led to greater insight into evolutionary and ecological processes in plant populations? In: (eds) Hails, S. R. Beringer, E. J.; Charles, H. and Godfray, J. Genes in the Environment: 15th Special Symposium of the British Ecological Society. Cambridge. University Press, Pp112- 132 .

Soysal, M.İ.; Özkan, E. Kök, S. Tuna, Y.T. and Gürcan, E.K. (2005). Genetic Characterization of Indigenous Anatolian Water Buffalo Breed Using Microsatellite DNA Markers. Journal of Tekirdag Agricultural Faculty, 2(3): 240-244.

Vaiman, D.; Mercier, D.; Moazami-Goudarzi, K.; Eggen, A.; Ciampolini, R.; Lepingle, A.; Velmala, R.; Kaukinen, J.; Varvio, S.L. and Martin, P. (1994a): A set of 99 cattle microsatellites: characterization, synteny mapping, and polymorphism. Mamm. Genome, 5(5):288-297.

Van Hooft, W.F.; Groen, A.F. and Prins, H.H. (1999): Microsatellite analysis of genetic diversity in African buffalo (Syncerus caffer) populations throughout Africa. Mol. Ecol., 9(12):2017-2025.

Ward, R.D, Skibinski, D.O.F and Woodwark, M. (1992). Protein heterozygosity, protein structure, and taxonomic differentiation. Evol. Biol, 26: 73-159.

Weber, J. L. and C. Wong, (1993). Mutation of human short tandem repeats. Hum. Mol. Genet., 2: 1123-1128.

Yeh, F.C.; Boyle, T.; Rongcai, Y.; Ye, Z. and Xian, J.M. (1999): POPGENE, Version 1.31. A Microsoft Window Based Free Ware for Population Genetic Analysis. University of Alberta, Edmonton.

\footnotetext{
التنوع الوراثى في الجاموس المصرى بإستخدام واسمات التوابع الو راثية الدقيقة

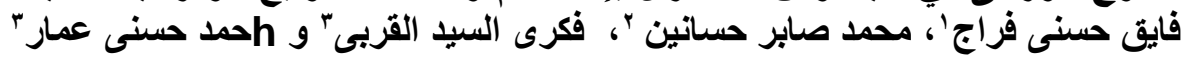

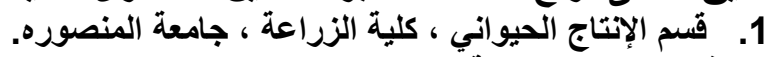

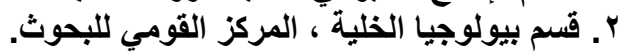

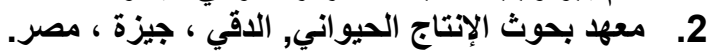

لار استة التباين الو راثي في الجاموس المصرى، تم تحديد التراكيب الجينيـة لأربعها وستون رأسـا من

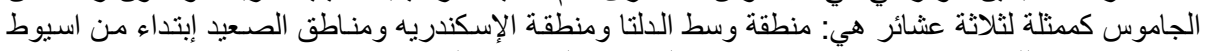

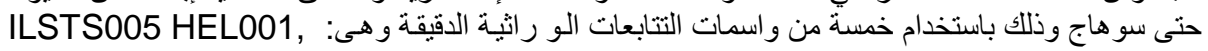

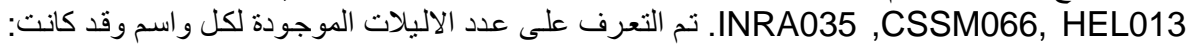

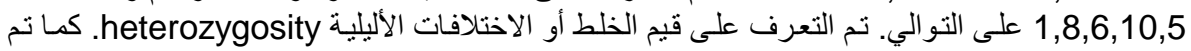

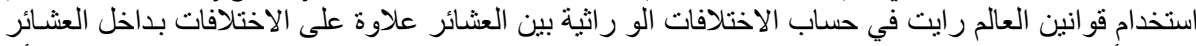

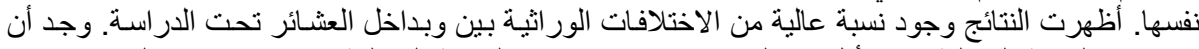

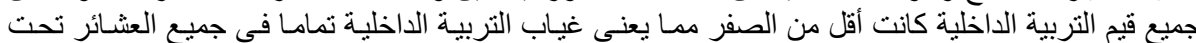

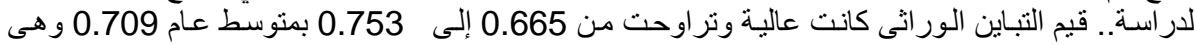

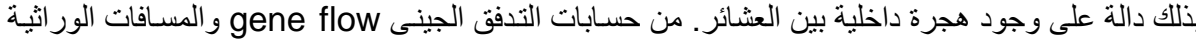
تم إعداد دندوجر ام يوضح العلاقة المحتملة بين العشائر تحت الدراسة.
} 